\title{
EVALUASI MANAJEMEN PENDIDIKAN KARAKTER SISWA SMAN 2 BANGUNTAPAN
}

\author{
Oleh: Ngadiya \\ Magister Manajemen, STIE Widya Wiwaha, Yogyakarta \\ Email: ngadiya59@yahoo.com
}

\begin{abstract}
The aim of this study was identify the management of student's character education SMAN 2 Banguntapan. This study applied a qualitative approach. The data collecting techniques were observation, interview, and documentation. Data collected from that technique were analyzed by using data reduction, data presentation, and verification. The results of this study reveal that the implementation of character education in SMAN 2 Banguntapan has been integrated in school activity on three main form: (1) combine with learning activities, (2) combine with extracurricular activities, (3) combine with cultivation and making people accustomed. The management of student's character education in SMAN 2 Banguntapan students is consist of: (1) the planning of character education; (2) the organization of character education; (3) the implementation of character education; and (4) the supervision of character education.
\end{abstract}

Keywords: character, character education, character education management

\section{PENDAHULUAN}

Pendidikan merupakan kegiatan yang dikakukan manusia untuk mengembangkan potensi yang dibawa sejak manusia itu lahir di dunia. Aktifitas pendidikan akan terus berlangsung sejak manusia pertama ada di dunia hingga berahirnya kehidupan di muka bumi ini (Al-Fandi, 2011: 25). Menurut Ki Hajar Dewantara sebagaimana dikutip dalam buku pendidikan multikultural, pendidikan adalah daya upaya untuk memajukan pertumbuhan budi pekerti (kekuatan batin, karakter), pikiran, dan tubuh anak (Mahfud, 2010: 33). Mengacu pada pengertian tersebut pendidikan berarti rambu-rambu yang diberikan kepada peserta didik agar melakukan kodratnya sebagai makhluk terdidik, mampu membawa potensi dirinya, serta dalam kehidupan selanjutnya akan mempunyai batasan-batasan kehidupan sesuai norma yang berlaku. Abad ke-21 membawa perubahan era yang populer dengan sebutan era globalisasi. Dampak globalisasi yang terjadi saat ini membawa masyarakat Indonesia melupakan pendidikan karakter bangsa. Pendidikan karakter bangsa merupakan pondasi bagi suatu bangsa dalam upaya membantu perkembangan jiwa anakanak baik lahir maupun batin. Pendidikan karakter merupakan proses berkelanjutan dan tidak pernah berakhir selama manusia masih ada di muka bumi ini. Oleh karena itu, dalam rangka tujuan pendidikan karakter, perlu ada manajemen yang baik dan sinergis di antara berbagai komponen pendidikan yang terlibat baik yang bersifat formal, nonformal, maupun informal, baik di sekolah, keluarga, maupun masyarakat (Harun, 2013: 302). Karakter adalah perilaku manusia yang berhubungan dengan Tuhan Yang Maha Esa, diri sendiri, sesama manusia, lingkungan, dan kebangsaan yang terwujud dalam pikiran, sikap, perasaan, perkataan, dan perbuatan berdasarkan normanorma (Heri Gunawan, 2012:4)

Pendidikan karakter di sekolah/ madrasah, semua komponen (stakeholders) harus dilibatkan, termasuk komponenkomponen pendidikan itu sendiri, yaitu isi kurikulum, proses pembelajaran dan penilaian, kualitas hubungan, penanganan atau pengelolaan mata pelajaran, pengelolaan sekolah, pelaksanaan aktivitas atau kegiatan ko- kurikuler, pemberdayaan sarana prasarana, pembiayaan, dan ethos kerja seluruh warga dan lingkungan sekolah.

Pendidikan karakter di sekolah/ madrasah dapat optimal, efektif, dan efisien, maka diperlukan kegiatan manajemen yang efektif dan efisien. Oleh karena itu, pendidikan karakter di sekolah sekolah/ 
madrasah juga sangat terkait dengan manajemen atau pengelolaan sekolah/ madrasah. Pengelolaan yang dimaksud adalah bagaimana pendidikan karakter direncanakan, dilaksanakan, dan dikendalikan dalam kegiatan-kegiatan pendidikan di sekolah/ madrasah secara memadai. Dengan demikian, manajemen sekolah merupakan salah satu media yang efektif dalam pendidikan karakter di sekolah/madrasah.

Penelitian memilih SMAN 2 Banguntapan sebagai obyek penelitian. Alasannya adalah pertama, Sekolah merupakan lembaga pendidikan formal. Di Kabupaten Bantul, terdapat 33 SMA Negeri dan swasta. Kedua, sekolah tersebut jika dilihat secara hierarki sistem administrasi nasional di negara kita, terdapat di perbatasan wilayah perkotaan dan pedesaan di Kabupaten Bantul yang berada di wilayah utara berbatasan dengan Kota Yogyakarta, sehingga permasalahan karakter siswa semakin kompleks. Ketiga, berdasarkan observasi awal yang dilakukan, kedisiplinan sangat ditekankan di sekolah ini. Siswa harus berada di sekolah sebelum jam 07.00. Sesudah jam tersebut, pintu gerbang ditutup oleh satpam. Siswa-siswa yang terlambat mendapatkan sanksi/pembinaan. Sigit Purwanto bagian kesiswaan SMAN 2 Banguntapan menyatakan bahwa dalam tiga tahun terakhir masih ada kasus pelanggaran tata tertib peserta didik SMAN 2 Banguntapan seperti datang terlambat, menyontek pada saat ulangan, perkelahian antar teman, membawa rokok/ senjata tajam di sekolah.

Berdasarkan latar belakang yang telah diuraikan di atas, maka yang menjadi rumusan masalah dalam penelitian ini adalah pelaksanaan manajemen pendidikan karakter siswa di SMAN 2 Banguntapan belum optimal. Penelitian ini bertujuan untuk mengevaluasi pelaksanaan manajemen pendidikan karakster siswa di SMAN 2 Banguntapan tahun 2018.

Penelitian Terdahulu
Beberapa penelitian yang telah dilakukan dapat memberikan bukti terkait evaluasi manajemen pendidikan karakter siswa, antara lain penenlitian (Harun, 2013) yang menunjukkan bahwa keluarga dan kurikulum berperan dalam pendidikan nasional. Penelitian (Rimawan dan Irene, 2014) tentang manajemen pendidikan karakter yang dilakukan di SMA De Britto dan faktor pendukung serta penghambatnya. Penelitian (Banawi, 2009) yang menunjukkan bahwa pembelajaran IPA yang berbasis karakter efektif dalam meningkatkan budi pekerti siswa sekolah dasar. Penelitian (Wibowo, 2010) menjelaskan bahwa pendidikan karakter dapat dilakukan dengan berbagai cara seperti indoktrinasi, modeling, dan klarifikasi nilai. Penelitian (Muhtadi, 2015) memperoleh hasil bahwa untuk mengimplementasikan pendidikan budi pekerti di sekolah dapat dilakukan melalui empat cara.

\section{Manajemen Pendidikan}

Manajemen adalah proses sosial yang berkenaan dengan keseluruhan usaha manusia dengan bantuan manusia lain serta sumbersumber lainnya, menggunakan metode yang efisien dan efektif untuk mencapai tujuan yang ditentukan sebelumnya (Hamalik, 2010:16). Kemudian manajemen diartikan sebagai caracara pengelolaan suatu lembaga agar supaya lembaga tersebut efisien dan efektif. Lembaga kategori efisien apabila investasi yang ditanam sesuai dan memberikan profit sesuai harapan. Suatu lembaga disebut efektif apabila pengelolaan lembaga menggunakan prinsip yang tepat sehingga kegiatannya dapat mencapai tujuan yang telah direncanakan (Tilaar, 2009: 11).

Pendidikan ditinjau dari segi pedagogik adalah upaya untuk menumbuh-kembangkan potensi-potensi bawaan peserta didik, baik jasmani maupun rohani sesuai nilai yang ada pada masyarakat dan kebudayaan (Mahfud, 2010: 47).

Dalam pengertian lain pendidikan adalah usaha untuk membantu, melatih, dan mengarahkan anak melalui transmisi 
pengetahuan, pengalaman, intelektual dan keberagamaan sesuai dengan fitrah manusia supaya dapat berkembang sampai pada tujuan yang dicita-citakan, yaitu kehidupan yang sempurna dengan terbentuknya kepribadian yang utama (Al-Fandi, 2010: 100).

Manajemen pendidikan diartikan sebagai proses keseluruhan kegiatan bersama dalam bidang pendidikan yang meliputi perencanaan, pengorganisasian, pengarahan, pelaporan, pengkoordinasian, pengawasan dan evaluasi menggunakan sarana prasarana yang tersedia baik personil, materil maupun spiritual untuk mencapai tujuan pendidikan secara efektif dan efisien (Nata, 2008:24).

Manajemen pendidikan mempunyai fungsi, diantaranya yang telah diutarakan oleh beberapa tokoh pendidikan sebagai berikut. (1) Fayol, mengemukakan proses manajemen terdiri dari fungsi planning, organizing, commanding, coordinating, dan controlling, (2) Gulick mengemukakan proses manajemen terdiri dari: planning, organizing, staffing, directing, coordinating, reporting, dan budgeting, (3) Newman merumuskan proses manajemen diawali dari: melakukan planning, organizing, assembling resources, directing, dan controlling, (4) Sears menyatakan proses manajemen dilakukan dari: planning, organizing, directing, coordinating, dan controlling (Imron, 2003: 6). Kemudaian pendapat yang lain yaitu terdapat empat fungsi manajemen yang terpenting yaitu 1) Planning (perencanaan), 2) Organizing (pengorganisasian), 3) Actuating (pelaksanaan), 4) Controling atau pengawasan (Terry dalam Ambarita, 2013: 18). Dan pendapat yang terahir mengenai fungsi manajemen pendidikan mempunyai 5 poin penting, yaitu perencanaan, organisasi, kordinasi, pelaksanaan (penggerakan), dan fungsi kontrol (Hamalik, 2010: 81). Dari paparan tentang fungsi manajemen di atas, peneliti menyimpulkan bahwa fungsi manajemen setidaknya terdapat lima poin penting, yaitu perencanaan, pengorganisasian, koordinasi, pelaksanaan, dan fungsi kontrol.

\section{Pendidikan Karakter}

Pendidikan karakter merupakan sebuah usaha untuk mendidik anak-anak agar dapat mengambil keputusan dengan bijak dan mempraktikkan dalam kehidupan sehari-hari, sehingga mereka dapat memberikan kontribusi yang positif kepada lingkungannya (Megawangi, 2004: 95). Selanjutnya pendidikan karakter adalah penanaman dan pengembangan karakter-karakter luhur kepada anak didik, sehingga mereka memiliki karakter luhur itu, menerapkan dan mempraktikkan dalam kehidupannya baik di keluarga, masyarakat, dan negara (Wibowo, 2012:36).

Pendidikan karakter mempunyai tujuan untuk meningkatkan mutu proses dan hasil pendidikan yang mengarah pada pembentukan karakter dan akhlak mulia peserta didik secara utuh, terpadu, seimbang, sesuai denga standar kompetensi lulusan pada setiap satuan pendidikan (Mulyasa, 2014: 9). Jadi pendidikan yang didapat dari bangku pendidikan diharapkan mampu meningkatkan pengetahuannya, mengkaji dan mempersonalisasikan nilai-nilai karakter dalam kehidupan sehari-hari.

Pendekatan pembelajaran dalam pendidikan karakter mengharuskan adanya pendekatan andragogik selain pedagogik yang dominan dalam pembelajaran. Pedagogik dan andragogik merupakan dua sisi pendekatan yang bukan dikotomis akan tetapi berupa kontinum dalam proses pembelajaran manusia, dan sangat mungkin jika keduanya diterapkan dalam praktek pendidikan terutama penerapan pendidikan karakter (Mulyasa, 2014: 135).

Model pembelajaran pendidikan karakter merupakan bentuk cara agar pendidikan karakter yang diinginkan tercapai. Model pembelajaran pendidikan karakter diantaranya pembiasaan, keteladanan, pembinaan disiplin peserta didik, CTL (Contextual Teaching and Learning), bermain peran, pembelajaran partisipatif, dan urgensi pendidikan karakter.

\section{METODE PENELITIAN}


Penelitian ini menggunakan penelitian kualitatif deskriptif. Lokasi penelitian ini adalah di SMAN 2 Banguntapan yang beralamat di Glondong, Wirokerten, Kecamatan Banguntapan, Bantul, Daerah Istimewa Yogyakarta.

Penelitian ini menggunakan sumber data primer yang diperoleh melalui bentuk wawancara yang semi terstruktur, dan pengamatan lapangan dengan responden. Responden pada penelitian ini yaitu Tri Giharto, Afiri Nofi Kurniawan, dan guru di SMAN 2 Banguntapan. Pada penelitian ini sumber sekunder yang digunakan berupa literatur artikel, serta situs di internet yang berkenaan dengan penelitian yang dilakukan.

Penelitian ini menggunakan teknik wawancara, observasi, dan dokumentasi. Wawancara yang digunakan berbentuk wawancara semi terstruktur. Observasi yang dilakukan menggunakan bentuk observasi nonpartisipatif. Dengan demikian maka peneliti akan datang di SMAN 2 Banguntapan tetapi tidak ikut terlibat dalam kegiatan yang diamati. Dokumen yang digunakan berupa catatan, transkip, buku, dan sebagainya.

Penelitian ini menggunakan teknik analisis data model Miles dan Huberman yang meliputi pengumpulan data, reduksi data (data reduction), penyajian data (data display), dan penarikan kesimpulan.

\section{HASIL DAN PEMBAHASAN}

\section{Perencanaan Pendidikan Karakter SMAN} 2 Banguntapan

Berdasarkan hasil temuan di lapangan dapat dipaparkan bahwa perencanaan pendidikan karakter SMAN 2 Banguntapan sesuai dengan tahap penyusunan rancangan pendidikan karakter Kementerian Pendidikan dan Kebudayaan, yang menyatakan bahwa beberapa hal yang perlu dilakukan dalam tahap penyusunan rancangan pendidikan karakter antara lain: 1) Jenis-jenis kegiatan pendidikan karakter di sekolah telah direalisasikan kepada peserta didik dalam kehidupan sehari-hari, 2) Materi pembelajaran telah dikembangkan sesuai dengan kegiatan di sekolah, 3) Fasilitas pendukung pelaksanaan program pembentukan karakter di sekolah telah disiapkan dengan baik.

Perencanaan pendidikan karakter SMAN 2 Banguntapan dibagi melalui:

a. Perencanaan Pendidikan Karakter dalam Pembelajaran

Berdasarkan hasil temuan di lapangan dapat dipaparkan bahwa perencanaan pembelajaran yang telah disusun guru SMAN 2 Banguntapan sesuai dengan pedoman pelaksanaan pendidikan karakter di sekolah dari Kementerian Pendidikan dan Kebudayaan yang menyatakan bahwa pada tahap perencanaan pembelajaran Silabus, RPP dan bahan ajar dirancang agar muatan maupun kegiatan pembelajarannya memfasilitasi / berwawasan pendidikan karakter. Yang dilakukan guru untuk membuat silabus, RPP, dan bahan ajar yang berwawasan pendidikan karakter sesuai dengan pedoman pelaksanaan pendidikan karakter di sekolah dari Kementerian Pendidikan dan Kebudayaan dengan mengadaptasi silabus, RPP, dan bahan ajar yang telah dibuat/ada dengan menambahkan/ mengadaptasi kegiatan pembelajaran yang bersifat memfasilitasi dikenalnya nilai- nilai, disadarinya pentingnya nilai-nilai, dan diinternalisasinya nilai- nilai.

Hal tersebut dapat diketahui bahwa guru membuat perencanaan pembelajaran dalam bentuk silabus, dan RPP (Rencana Pelaksanaan Pembelajaran) setiap awal pergantian tahun ajaran baru.

Komponen silabus yang disusun guru SMAN 2 Banguntapan meliputi identitas mata pelajaran, identitas sekolah, kompetensi inti, kompetensi dasar, materi pokok, pembelajaran, peniliaian, alokasi waktu, sumber belajar, dan nilai karakter yang diintegrasikan.

Rencana Pelaksanaan Pembelajaran (RPP) yang disusun guru SMAN 2 Banguntapan memiliki komponen nama satuan pendidikan; identitas mata pelajaran; kelas/semester; materi pokok; alokasi waktu, 
tujuan pembelajaran, nilai karakter yang diinternalisasikan, kompetensi dasar dan indikator pencapaian kompetensi; materi pembelajaran, metode pembelajaran, media pembelajaran, sumber belajar, langkahlangkah pembelajaran, dan penilaian hasil pembelajaran.

b. Perencanaan Pendidikan Karakter dalam Kegiatan Ekstrakurikuler.

Berdasarkan hasil temuan di lapangan melalui wawancara dengan kepala sekolah dapat dipaparkan bahwa perencanaan pendidikan karakter dalam kegiatan ekstrakurikuler SMAN 2 Banguntapan sesuai dengan panduan kegiatan ekstrakurikuler pendidikan karakter Kementerian Pendidikan dan Kebudayaan, yang menyatakan bahwa perencanaan kegiatan ekstrakurikuler di satuan pendidikan dilakukan melalui tahapan (1) analisis sumber daya yang diperlukan dalam penyelenggaraan kegiatan ekstrakurikuler; (2) identifikasi kebutuhan, potensi, dan minat peserta didik; (3) menetapkan bentuk kegiatan yang diselenggarakan; (4) mengupayakan sumber daya sesuai pilihan peserta didik atau menyalurkannya ke satuan pendidikan atau lembaga lainnya; (5) menyusun Program Kegiatan Ekstrakurikuler.

Perencanaan pendidikan karakter dalam kegiatan ekstrakurikuler SMAN 2 Banguntapan disesuaikan dengan kebutuhan dan potensi yang dimiliki oleh madrasah yang meliputi analisis kebutuhan, perencanaan dana dan sarana, manfaat bagi siswa dan madrasah, dan menyusun program kegiatan ekstrakurikuler. Program kegiatan ekstrakurikuler disusun oleh masing-masing pembina ekstrakurikuler.

SMAN 2 Banguntapan merencanakan kegiatan ekstrakurikuler yang akan dilaksanakan pada tahun 2018/2019 antara lain ekstrakurikuler pramuka, ekstrakurikuler palang merah remaja (PMR), ekstrakurikuler Karya Ilmiah Remaja (KIR), ekstrakurikuler Kerohanian dan Peribadatan, ekstrakurikuler olah raga dan Kesehatan, ekstrakurikuler kesenian dan estetika. c. Perencanaan Pendidikan Karakter dalam Kegiatan Pembudayaan dan Pembiasaan

Berdasarkan hasil temuan di lapangan dapat dipaparkan bahwa perencanaan pendidikan karakter dalam kegiatan pembudayaan dan pembiasaan SMAN 2 Banguntapan dirancang pada awal tahun pelajaran. Hal ini sesuai dengan pedoman pelaksanaan pendidikan karakter Kementerian pendidikan dan kebudayaan, yang menyatakan bahwa kegiatan sekolah yang diikuti seluruh atau sebagian peserta didik, guru, kepala sekolah, dan tenaga administrasi di sekolah itu, direncanakan sejak awal tahun pelajaran, dimasukkan ke Kalender Akademik dan yang dilakukan sehari-hari sebagai bagian dari budaya sekolah.

Jenis kegiatan yang direncanakan dalam pengembangan budaya sekolah dilakukan melalui kegiatan pengembangan diri, yaitu: kegiatan rutin, kegiatan spontan, keteladanan, dan pengkondisian.

Perencanaan pendidikan karakter dalam kegiatan budaya sekolah SMAN 2 Banguntapan meliputi kegiatan rutin, kegiatan insidental, pengkondisian, dan keteladanan. Kegiatan rutin yang diselenggarakan SMAN 2 Banguntapan seperti salam dan salim, berdo'a bersama di pagi hari, piket harian kelas, upacara bendera, jumat bersih, dan senam bersama. Sedangkan kegiatan insidental yang ada di SMAN 2 Banguntapan antara lain, lomba olah raga antar kelas, penanaman 100 pohon, lomba pidato, lomba kebersihan antar kelas, SMAN 2 Banguntapan melakukan pengkondisian dengan merencanakan penyediaan berbagai fasilitas belajar dan fasilitas sumber belajar yang menyenangkan, dan menciptakan lingkungan kondusif, baik fisik maupun non-fisik.

Pengorganisasian Pendidikan Karakter SMAN 2 Banguntapan

a. Pembagian Tugas Guru dalam Kegiatan Pembelajaran

Berdasarkan hasil temuan di lapangan dapat peneliti paparkan bahwa pembagian tugas guru dalam kegiatan pembelajaran 
SMAN 2 Banguntapan sesuai dengan buku pedoman pelaksanaan tugas guru dan pengawas yang meliputi ruang lingkup kerja guru, jam kerja, uraian tugas per jenis guru, dan pemenuhan kewajiban jam tatap muka guru. Pembagian tugas guru dalam kegiatan pembelajaran tertuang dalam Surat Keputusan Kepala SMAN 2 Banguntapan Nomor 115/500 tanggal 5 Juli 2018 tentang susunan organisasi dan pembagian tugas bagi guru dan personalia ketatausahaan SMAN 2 Banguntapan tahun pelajaran 2018/2019.

b. Pembagian Tugas Guru dan Karyawan dalam Kegiatan Esktrakurikuler

Berdasarkan hasil temuan dapat dipaparkan bahwa pembagian tugas guru dalam kegiatan ekstrakurikuler sesuai dengan pedoman kegiatan eksrakurikuler kementerian pendidikan dan kebudayaan yaitu Peraturan Menteri Pendidikan dan Kebudayaan yang menyatakan bahwa pelaksanaan kegiatan ekstrakurikuler harus didukung dengan ketersediaan pembina. Ketersediaan Pembina ini tertuang dalam Lampiran 3 SK Kepala SMAN 2 Banguntapan nomor 115/500 tanggal 5 Juli 2018 tentang pembagian tugas guru dalam kegiatan bimbingan dan penyuluhan SMAN 2 Banguntapan.

c. Pembagian Tugas Guru dan Karyawan dalam Kegiatan Pembudayaan dan Pembiasaan

Berdasarkan hasil temuan di lapangan dapat dipaparkan bahwa pembentukan panitia atau penanggung jawab kegiatan pembudayaan dan pembiasaan merupakan kunci sukses terselenggaranya kegiatan pembudayaan dan pembiasaan yang ada di SMAN 2 Banguntapan. Dengan adanya panitia atau penanggung jawab kegiatan, pelaksanaan kegiatan menjadi terarah sesuai dengan program yang telah ditetapkan.

\section{Pelaksanaan Pendidikan Karakter SMAN}

\section{Banguntapan}

a. Pelaksanaan Pendidikan Karakter dalam Pembelajaran

Berdasarkan hasil temuan di lapangan dapat dipaparkan bahwa pelaksanaan pendidikan karakter dalam pembelajaran SMAN 2 Banguntapan sesuai dengan pedoman pelaksanaan pendidikan karakter Kementerian Pendidikan dan Kebudayaan, yang menyatakan bahwa kegiatan pembelajaran dari tahapan kegiatan pendahuluan, inti, dan penutup, dipilih dan dilaksanakan agar peserta didik mempraktikkan nilai-nilai karakter yang ditargetkan.

Pelaksanaan Pendidikan Karakter dalam Pembelajaran SMAN 2 Banguntapan juga sesuai dengan Peraturan Menteri Pendidikan dan Kebudayaan Nomor 81a Tahun 2013 lampiran IV Tentang Implementasi Kurikulum, yang menyatakan bahwa proses pembelajaran terdiri atas lima pengalaman belajar pokok yaitu: mengamati; menanya; mengumpulkan informasi; mengasosiasi; dan mengkomunikasikan.

Berdasarkan observasi, karakteristik pembelajaran SMAN 2 Banguntapan dilakukan secara efektif, efisien, aktif, kreatif, inovatif, menyenangkan, dan mencerdaskan. Tujuan pembelajaran dapat dicapai oleh peserta didik sesuai yang diharapkan. Peserta didik tidak hsanya menguasai kompetensi kognisi saja, tetapi juga kompetensi afeksi, dan psikomotor. Aktivitas pembelajaran berfokus dan didominasi Siswa. Guru secara aktif memantau, membimbing dan mengarahkan kegiatan belajar siswa.

Proses pembelajaran SMAN 2 Banguntapan terdiri dari kegiatan pendahuluan, inti, dan penutup. Nilai karakter yang ditanamkan dalam kegiatan pendahuluan antar lain, guru datang tepat waktu. Nilai yang ditanamkan adalah disiplin. Guru mengucapkan salam dengan ramah kepada siswa ketika memasuki ruang kelas. Nilai yang ditanamkan adalah santun dan peduli. Berdoa sebelum membuka pelajaran. Nilai yang ditanamkan adalah religius. Mengecek kehadiran siswa. Nilai yang ditanamkan adalah disiplin dan rajin. Mendoakan siswa yang tidak hadir karena sakit atau karena halangan lainnya. Nilai yang ditanamkan 
adalah religius dan peduli. Memastikan bahwa setiap siswa datang tepat waktu. Nilai yang ditanamkan adalah disiplin. Menegur siswa yang terlambat dengan sopan. Nilai yang ditanamkan adalah disiplin, santun, dan peduli. Dengan merujuk pada silabus, RPP, dan bahan ajar, menyampaikan butir karakter yang hendak dikembangkan selain yang terkait dengan $\mathrm{KI} / \mathrm{KD}$.

b. Pelaksanaan Pendidikan Karakter dalam Kegiatan Ekstrakurikuler

Berdasarkan hasil temuan di lapangan dapat dipaparkan bahwa pelaksanaan pendidikan karakter dalam kegiatan ekstrakurikuler SMAN 2 Banguntapan sesuai dengan Pedoman Pelaksanaan Pendidikan karakter Kementerian Pendidikan dan Kebudayaan, yang menyatakan bahwa ekstrakurikuler merupakan bagian dari program pembinaan kesiswaan, yang termasuk kelompok bidang peningkatan mutu pendidikan. Artinya, kegiatan ekstrakurikuler dirancang dalam rangka meningkatkan mutu pendidikan di sekolah, yang memperkuat penguasaan kompetensi dan memperkaya pengalaman belajar peserta didik melalui kegiatan di luar jam pelajaran.

SMAN 2 Banguntapan menyelenggarakan kegiatan ekstrakurikuler yang terdiri dari Pramuka, Palang Merah Remaja (PMR), Karya Ilmiah Remaja (KIR), Kerohanian dan Peribadatan, Olah Raga dan Kesehatan, Kesenian dan Estetika, serta ekstrakurikuler Majalah Dinding.

c. Pelaksanaan Pendidikan Karakter dalam

Kegiatan Pembudayaan dan Pembiasaan

Berdasarkan hasil temuan di lapangan dapat dipaparkan bahwa pelaksanaan kegiatan pembudayaan dan pembiasaan SMAN 2 Banguntapan sesuai dengan pedoman pelaksanaan pendidikan karakter Kementerian Pendidikan dan Kebudayaan, yang menyatakan bahwa pengembangan budaya sekolah kegiatan belajar dilakukan melalui kegiatan pengembangan diri, yaitu: kegiatan rutin, kegiatan spontan, keteladanan, dan pengkondisian.
Kegiatan rutin yang dilaksanakan SMAN 2 Banguntapan antara lain upacara bendera, senam bersama, berdo'a bersama, peringatan hari besar nasional, peringatan hari besar agama, Jumat bersih dan piket kelas.

Kegiatan insidental yang dilaksanakan SMAN 2 Banguntapan antara lain lomba olah raga antar kelas, penanaman 100 pohon, lomba pidato, lomba kebersihan antar kelas, penyuluhan KRR, bakti sosial, dan peringatan bulan bahasa.

Kegiatan pengkondisian dan keteladanan yang dilakukan SMAN 2 Banguntapan antara lain lingkungan sekolah bersih, rapi, aman, sehingga menyenangkan bagi semua warga sekolah dan komitmen guru dan karyawan dalam memberikan teladan yang baik.

Pengawasan Pendidikan Karakter SMAN 2 Banguntapan

a. Pengawasan Pendidikan Karakter dalam Pembelajaran

Pengawasan pendidikan karakter dalam pembelajaran secara langsung dilakukan oleh guru mata pelajaran. Guru memegang peranan yang sangat strategis terutama dalam mengawasi hubungan antar siswa dalam kegiatan pembelajaran di kelas, membentuk karakter, dan mengembangkan potensi siswa. Pengawasan pendidikan karakter dalam pembelajaran secara langsung oleh kepala sekolah hanya dilakukan ketika melakukan supervisi.

b. Pengawasan Pendidikan Karakter dalam Kegiatan Ekstrakurikuler.

Pengawasan pendidikan karakter dalam kegiatan ekstrakurikuler secara langsung dilakukan oleh guru pembina ekstrakurikuler. Pengawasan pendidikan karakter dalam kegiatan ekstrakurikuler oleh kepala sekolah dilakukan dengan dua cara, yaitu secara langsung dan tidak langsung. Pengawasan pendidikan karakter dalam kegiatan ekstrakurikuler secara langsung oleh kepala sekolah dilakukan ketika kepala sekolah mengikuti kegiatan ekstrakurikuler, dan pengawasan pendidikan karakter dalam 
kegiatan ekstrakurikuler secara tidak langsung oleh kepala sekolah dilakukan dengan cara mengecek laporan bulanan.

Guru pembina ekstrakurikuler memegang peranan yang sangat strategis terutama dalam mengawasi kegiatan ekstrakurikuler, membentuk karakter, dan mengembangkan potensi siswa.

c. Pengawasan Pendidikan Karakter dalam Kegiatan Pembudayaan dan Pembiasaan.

Pengawasan pendidikan karakter dalam kegiatan pembudayaan dan pembiasaan secara langsung dilakukan oleh semua komponen sekolah, terutama guru dan tenaga kependidikan. Guru penanggung jawab kegiatan pembudayaan dan pembiasaan memegang peranan yang sangat strategis terutama dalam mengawasi jalannya kegiatan agar sesuai dengan yang direncanakan.

Berdasarkan hasil temuan di lapangan dapat dipaparkan bahwa pengawasan pendidikan karakter SMAN 2 Bangutapan yang bernuansa pendidikan karakter dengan melibatkan semua komponen yang ada di sekolah.

Ketika siswa yang berperilaku menyimpang maka guru yang mengetahui secara spontan akan menegur/memberi pembinaan langsung. Jika masalahnya berulang dan membutuhkan penanganan khusus pembinaan dilakukan secara bertahap, mulai dari pemanggilan siswa oleh wali kelas untuk mendapatkan pengarahan, jika masalah belum bisa diselesaikan bisa di koordinasikan dengan guru BK, namun jika perilaku yang ditimbulkan belum bisa terselesaikan bisa diselesaikan ke bagian kesiswaan hingga pemanggilan orang tua siswa. Selain itu, dalam melaksanakan pengawasan dan evaluasi sekolah menjalin kerjasama dengan pihak-pihak lainnya (stakeholders) serta menjalin partisipasi warga sekolah dan para pemangku kepentingan, dengan prinsip terbuka dan akuntabel.

Proses pengawasan pendidikan karakter dilakukan oleh kepala sekolah dan semua komponen sekolah. Secara administratif, pengawasan dilakukan oleh kepala sekolah terhadap dokumen pelaksanaan kegiatan yang dimiliki penanggungjawab/ pelaksana kegiatan. Hasil pengawasan menjadi bahan acuan untuk pengelolaan pendidikan karakter tahun yang akan datang, sehingga sekolah ini secara berkesinambungan mengembangkan pendidikan karakter dalam berbagai lini kehidupan sosial di sekolah.

\section{KESIMPULAN}

Berdasarkan hasil penelitian dan analisis data yang dilakukan mengenai manajemen pendidikan karakter di SMAN 2 Banguntapan, maka dapat diambil kesimpulan bahwa penyelenggaraan pendidikan karakter dilakukan secara terpadu pada setiap kegiatan sekolah melalui tiga jalur utama, yaitu kegiatan pembelajaran, ekstrakurikuler, serta pembudayaan dan pembiasaan. Pendidikan karakter di SMAN 2 Banguntapan sangat terkait dengan manajemen sekolah yang terdiri dari; tahap perencanaan, pengorganisasian, pelaksanaan, dan pengawasan

Pelaksanaan Pendidikan Karakter Siswa di SMAN 2 Banguntapan sudah sesuai dengan Permendikbud nomor 20 tahun 2018 tentang Penguatan Pendidikan Karakter (PPK) siswa, sebab 15 dari 18 karakter yang diharapkan sudah tercapai. Sehingga sudah memenuhi $15 / 18 \times 100 \%=83,33 \%$ nilai pencapian dengan kriteria BAIK.

Dalam perencanaan pendidikan karakter sebaiknya diawali dengan sosialisasi dengan menghadirkan ahli yang kompeten dalam bidang pendidikan karakter. Kegiatan ini bertujuan untuk membangun kesadaran kolektif tentang pentingnya pendidikan karakter pada sekolah, melakukan gerakan kolektif dan pencanangan pendidikan karakter untuk semua. Selain itu beberapa orang guru perlu diberikan kesempatan untuk magang di sekolah best practice yang ada di daerah lain yang menjadi sekolah piloting dalam implementasi pendidikan karakter. 


\section{DAFTAR PUSTAKA}

Al-Fandi, H. (2010). Desain Pembelajaran yang Demokratis dan Humanis. Yogyakarta: Ar-Ruzz Media.

Ambarita, A. (2013). Kepemimpinan Kepala Sekolah. Universitas Lampung

Gunawan, H. (2014). Pendidikan Karakter Konsep dan Implementasi. Bandung: Alfabeta

Hamalik, O. (2010). Manajemen Pengembangan Kurikulum. Bandung: Remaja Rosdakarya.

Harun, Zahri. (2013). Manajemen Pendidikan Karakter. Jurnal. Universitas Syiah Kuala. Tahun III. Nomor 3. Oktober.

Imron, Ali. dkk. (2003). Manajemen Pendidikan. Malang: Universitas Negeri Malang.

Mahfud, K. (2010). Pendidikan Multikultural. Yogyakarta: Pustaka Pelajar.
Muhtadi, A. (2018). Strategi Implementasi Pendidikan Budi Pekerti yang Efektif di Sekolah. www.staf.uny.ac.id. diuduh pada pukul 09.00. Juli.

Mulyasa, E. (2014). Manajemen Pendidikan Karakter. Jakarta: Bumi Aksara.

Nata, A. (2008). Manajemen Pendidikan Mengatasi Kelemahan Pendidikan di Indonesia. Jakarta: Kencana.

Peraturan Menteri Pendidikan dan Kabudayaan Republik Indonesia, nomor 20 tahun 2018 tentang Penguatan Pendidikan Karakter (PPK) pada Satuan Pendidikan Formal

Tilaar, H.A.R. (2009). Membenahi Pendidikan Nasional. Jakarta: Rineka Cipta.

Wibowo, A. (2012). Pendidikan Karakter: Strategi Membangun KarakterBangsa Berperadaban, Yogyakarta: Pustaka Pelajar. 